\title{
Research strategies to improve honeybee health in Europe*
}

\author{
Robin F.A. MORITZ ${ }^{1}$, Joachim de MIRANDA², Ingemar FrIES ${ }^{2}$, Yves LE CONTE ${ }^{3}$, \\ Peter NEUMANN ${ }^{4}$, Robert J. PAXTON ${ }^{5}$ \\ ${ }^{1}$ Institut für Biologie, Martin-Luther Universität Halle-Wittenberg, Hoher Weg 4, 06099 Halle a.d. Salle, \\ Germany \\ ${ }^{2}$ Department of Ecology, Sveriges Lantsbruks Universitet Uppsala, Sweden \\ ${ }^{3}$ UAPV Abeilles et Environnement, Institut National de la Recherche Agronomique, Avignon, France \\ ${ }^{4}$ Swiss Bee Research Centre, Agroscope Liebefeld-Posieux, Switzerland \\ ${ }^{5}$ School of Biological Sciences, Queens University, Belfast, UK
}

Received 5 October 2009 - Revised 26 January 2010 - Accepted 28 January 2010

\begin{abstract}
Understanding the fundaments of colony losses and improving the status of colony health will require cross-cutting research initiatives including honeybee pathology, chemistry, genetics and apicultural extension. The 7th framework of the European Union requested research to empirically and experimentally fill knowledge gaps on honeybee pests and diseases, including 'Colony Collapse Disorder' and the impact of parasites, pathogens and pesticides on honeybee mortality. The interactions among these drivers of colony loss will be studied in different European regions, using experimental model systems including selected parasites (e.g. Nosema and Varroa mites), viruses (Deformed Wing Virus, Black Queen Cell Virus, Israeli Acute Paralysis Virus) and model pesticides (thiacloprid, $\tau$-fluvalinate). Transcriptome analyses will be used to explore host-pathogen-pesticide interactions and identify novel genes for disease resistance. Special attention will be given to sublethal and chronic exposure to pesticides and will screen how apicultural practices affect colony health. Novel diagnostic screening methods and sustainable concepts for disease prevention will be developed resulting in new treatments and selection tools for resistant stock. Research initiatives will be linked to various national and international ongoing European, North- and South-American colony health monitoring and research programs, to ensure a global transfer of results to apicultural practice in the world community of beekeepers.
\end{abstract}

\section{Apis mellifera / pathology / diagnosis / disease resistance}

\section{INTRODUCTION}

\subsection{The value of honeybees and the costs of colony losses}

The management of honeybees, Apis mellifera, is deeply rooted in human society, and apiculture provides full or additional family income. There is a considerable market for bee products that are used as food and as additives for pharmaceutical and medical

Corresponding author: R. Moritz, robin.moritz@zoologie.uni-halle.de

* Manuscript editor: Marla Spivak products. More importantly from a strictly economic perspective, honeybees are key pollinators native to Europe and are crucial for many agricultural crops and the conservation of natural plant biodiversity. Indeed, honeybees are the most economically valued pollinators and it is estimated that $\sim 35 \%$ of human food consumption depends directly or indirectly on insect mediated pollination (Delaplane and Mayer, 2000), a vital ecosystem service contributing to human health and well-being. Although the direct value of the honey produced by the bee industry in the EU is about $€ 140$ Mio, the total added value to 
crops due to pollination services has recently been estimated at $€ 14.2$ billion in 2005 for the then 15 members of the EU. Worldwide, the total economic value of pollination by honeybee colonies amounted to $€ 153$ billion in 2005 (Gallai et al., 2008), while the value of bee pollination to biodiversity is simply inestimable; it is life itself. In light of the constant decline of wild non-honeybee pollinators, the importance of beekeepers and managed bees is greater today than ever.

Unfortunately, beekeeping is a declining industry and the past decades have seen a increase in colony losses in managed honeybee colonies (Potts et al., 2010) and an overall decrease of beekeeping activities in Europe (van Engelsdorp and Meixner, 2009). In addition and independent of the managed bee populations, wild or feral honey bee colonies are also in decline (Kraus and Page, 1995; Moritz et al., 2007; Jaffé et al., 2009) most likely due to intensification of land-use, pesticide poisoning, diseases and many parasites (in particular the ubiquitous ectoparasitic mite Varroa destructor).

The marked colony losses in Europe at the continental scale are unlikely to have been driven by pests, pathogens and pesticides. For example, the losses due to the appearance of Varroa destructor in the 1970s and 80s were largely compensated by beekeepers replacing their lost colonies with new ones, resulting in a constant rise in the number of managed honeybee colonies (Fig. 1). The most dramatic decline in managed colonies in Europe occurred in the 1990's coinciding with the sociocultural changes in eastern Europe whereas colony numbers remained stable in western Europe. With the lack of state support in the former socialistic countries many beekeepers in eastern Europe abandoned their operations causing a reduction in colony numbers by about $50 \%$. One of the principal reasons for the decline in managed honeybee colonies, and of beekeepers, is extensive and unpredictable colony death. While this can be discouraging enough for small-scale hobbyist beekeepers to drive them to abandon the hobby, for (semi)professional operators this is a crucial limitation to business planning and expansion. This has become most obvious in Eastern Europe

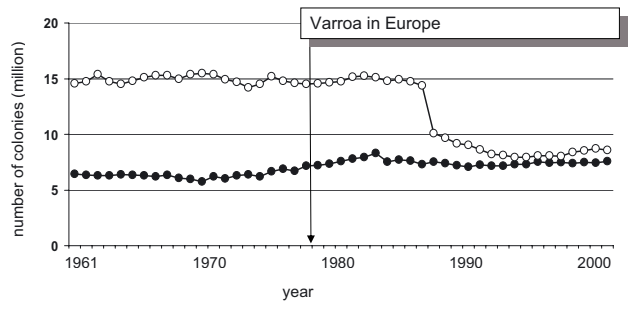

Figure 1. The annual number of hives reported to the FAO in western European countries (the former 15 EU member states, black circles) and the former Warsaw Pact countries in Europe (including the former USSR, open circles). The dramatic decline in Europe coincides with the political system changes in the in eastern Europe, whereas the introduction of Varroa destructor had no perceptible impact on the number of hives reported (data from FAOSTAT, 2009).

where the lack of state support forced beekeepers to not replace dead colonies, and instead abandon their apiaries altogether. Moderate and predictable losses can be accommodated and planned for. However, extensive and uncontrollable losses make beekeeping as a profession, with heavy investment in material and equipment, an enterprise at permanent risk of bankruptcy (van Engelsdorp et al., 2007). This financial uncertainty also limits recruitment of a new generation of beekeepers, especially to the professional ranks.

Periodic, extensive honeybee colony losses are not just a recent phenomenon. For example, Ireland suffered "The great mortality of bees" in 950, and nationwide bee losses occurred again in 992 and 1443 (Flemming, 1871). Similar repeated honeybee mortalities have been recorded in other countries throughout history. From the late 19th century onwards there are references to such extensive colony losses (Underwood and van Engelsdorp, 2007), including the famous "Isle of Wight disease" of the early 1900's in England (Rennie et al., 1921; Bailey and Ball, 1991), the disappearing disease in the 19601970's in the USA (Wilson and Menapace, 1979), Varroa destructor and the "Bee Parasitic Mite Syndrome" of the 1980's-1990's (de Jong et al., 1982; Ball and Allen, 1988; Hung et al., 1995) and the mysterious bee losses in 
France in the late 1990's (Faucon et al., 2002). The most recent addition to this list is the Colony Collapse Disorder (CCD) in the USA that began in 2006-2007 (van Engelsdorp et al., 2007). In Europe similar phenomena have not been observed in the past decades and large number colony deaths are mostly locally confined (e.g. Genersch et al., 2010). For example the "Rhine valley bee poisoning" case of 2008 (Benjamin and McCallum, 2008) caused large scale colony collapses. The causes of regionally confined colony deaths usually become rapidly clear (e.g. for the Rhine valley poisoning and similar cases in France and Italy that were due to misuse of neonicotinoid pesticides) and appropriate actions can be taken to prevent future accidents. In contrast, the causes of most large scale colony losses at a national or even broader scale are still ambiguous or inconclusive (see Underwood and van Engelsdorp, 2007; Cox-Foster et al., 2007; Johnson et al., 2009; van Engelsdorp and Meixner, 2010) and have not yet been reported to reach a continental scale. Nevertheless, this uncertainty prevents the development of rational approaches to managing colony losses and encourages ad-hoc remedies and blanket prophylactic application of chemical treatments against pathogens or parasites, whether present or not. Such practices are also encouraged by the inadequate diagnostic tools and procedures for disease treatment. Typically, the apiculturist identifies symptoms at the colony level, and then initiates diagnostic procedures to identify the disease and initiate a treatment. Yet, when clinical symptoms appear at the colony level, diagnosis often comes too late to save or cure the colony. Consequently, there is a clear need for fast, reliable, sensitive and cheap diagnostic tools that alert the beekeeper to potential problems before colony level symptoms appear.

Treatments typically rely on chemicals, which are administered into the colony to target pathogens before colony death is inescapable. The development of such treatments is based on searching for chemicals that are toxic to the pathogen, but harmless to the honeybee. However, so far, any chemical treatment of a honeybee disease, even if suc- cessful at the colony level in the short term, has not eradicated the pathogen at the population level, particularly if the pathogen has a high transmission rate and a high infectivity. As illustrated by present apicultural reality, any chemotherapy of honeybee colonies immediately leads to unavoidable contamination of honey (Stanimirovic et al., 2005) and, ultimately more worrisome, to resistant pathogens. Moreover, the dramatic colony losses of the past decade suggest that treatments aiming at a single pathogen may in principle fall short in curing colonies altogether if the interactions between various pathogens are the main drivers of colony death.

\subsection{The parasite-virus-pesticide meltdown}

The most thorough search for a pathogenic cause of extensive, unexplained colony losses is the case of Colony Collapse Disorder (CCD; Cox-Foster et al., 2007; Johnson et al., 2009). However, despite the enormous research efforts invested, no single agent or factor has emerged as the definitive cause of the phenomenon (Stokstad, 2007; Anderson and East, 2008). Instead, the best hypothesis to emerge from the data is that particular virulent combinations of parasites and pathogens rather than a classical monocausal disease, is the most likely explanation (Chen and Evans, 2007; Johnson et al., 2009). Moreover, chronic exposures to pesticides that cause no problems for healthy colonies are suspected to interact with pathogens to produce lethal consequences for colonies already weakened by disease (Thompson, 2003). Both the European Commission (2007) and the European Parliament (2008) became aware of the problem for beekeeping and formulated research policies to address the issue. The aim was to prevent honeybee colony losses in Europe caused by the CCD syndrome and to better understand host/parasite/pesticide interactions as a potential driver of colony collapses. Hence in contrast to US research initiatives which aim at understanding past colony losses, European attempts have a clear preventive perspective aiming to understand potential principles of colony death. The classic example 
of such interactions among pathogens is the case of the ectoparasite Varroa destructor, whose lethal effect on colonies is in large part due to its ability to activate and transmit a number of viral diseases (Ball and Allen, 1988; Bailey and Ball, 1991; Bowen-Walker et al., 1999; Sumpter and Martin, 2004; Chen et al., 2005, 2006; Tentcheva et al., 2006; Todd et al., 2007). Recent evidence suggests that this may also be the case for other honeybee ectoparasites (Dainat et al., 2008; Forsgren et al., 2009). The combination of pests, parasites and pesticides results in an inadvertent "meltdown" with one negative factor enhancing the negative impacts on honeybee health of the others.

Appreciation of the fact that colonies suffer multiple infections and understanding the resultant interactions among pathogens, pesticides and management, will be central elements if we want to comprehend colony losses and develop sustainable strategies for promoting colony health. It will be essential to examine the nature of such relationships to identify the traits in the host and the parasite that enable increased tolerance and/or reduced virulence, respectively. This makes identifying the genes for host resistance or the management practices that reduce parasite virulence a realistic option. These ambitions will be greatly facilitated by the recent progress in the molecular characterization of bee viruses and other pathogens, to quantify their transmission efficacy and replication in relation to mite infestation levels and developmental stage of the bee. The discovery that parasites are not just virus vectors, but may also function as an alternative replicative host for certain viruses (Yue and Genersch, 2005; Gisder et al., 2009; Dainat et al., 2009; Eyer et al., 2009), significantly enhances the epidemiological potential and lethality of the virus infection for the honeybee, especially at colony level. The examination of the parameters determining the virulence of viruses (see de Miranda and Genersch, 2010), the tolerance of individual bees and colonies to virus infection, and the quantification of the interactions between parasite, virus, and pesticide at the various developmental stages of the honeybee will therefore need to be in the centre of interest.

\section{RESEARCH CONCEPTS}

\subsection{Strategy for studying interactions affecting colony health}

Honeybee pathology has identified a suite of detrimental factors that impact colony health, including parasites, pathogens and pesticides. A major problem is the combination of factors. A single infection may cause no harm to a colony, however, if exposed to a pesticide at the same time the colony might die. Interactions among sublethal factors affecting colony health therefore stand in the centre of European research in the years to come. Unfortunately, the large number of pests, pathogens and pesticides affecting honeybee health (Bailey and Ball, 1991; Thompson, 2003; Ellis and Munn, 2005) makes it impossible to experiment with all possible combinations of these in a rigorous, controlled manner. The "BEE DOC" (Bees in EuropE and the Decline Of Honeybee Colonies, http:// www.bee-doc.eu/) research network in the seventh EU Commission's Framework Programme (FP7) will therefore adopt a dualtrack approach to identifying significant interactions. First, an experimental approach will focus on major, pan-European parasites, pesticides and pathogens with known or suspected interactions among them, either detrimental or beneficial, including those factors thought to be associated with CCD in the United States. Second, a dynamic surveillance approach will be aimed at identifying significant associations among as many factors as possible, using both existing national monitoring surveys and comprehensive additional assays of the samples produced by the experimental approach. This strategy combines a detailed investigation of known interactions with the greatest current significance for colony health throughout Europe, with a comprehensive screen for possible interactions of future significance.

\subsection{Experimental test systems}

Following the strategy outlined above, we will focus research on selected test systems 
that can be used for detailed experimentation. These include:

Two major parasite-pathogen interactions

- Varroa destructor mites and deformed wing virus

- Nosema spp. Microsporidia, black queen cell virus and Israeli acute paralysis virus

Two widespread pesticides

o the neonicotinoid agro-pesticide thiacloprid

○ the pyrethroid beekeeping acaricide $\tau$ fluvalinate

Two categories of interactions between beneficial organism with pathogens

- Probiotic honeybee gut microflora and bacterial pathogens

- Propolis and plant secondary metabolites and parasites \& pathogens.

These must be studied at both individual bee and colony levels, since pathogen virulence at the individual level is often inversely related to virulence at colony level (Sumpter and Martin, 2004; Genersch et al., 2005), and also will include higher order interactions between the three categories; for example, between pesticides and parasite-pathogens, or between beneficial interactions and pesticides.

\subsection{Parasites}

\subsubsection{Varroa destructor}

The parasitic mite $V$. destructor is without doubt the main obstacle to profitable beekeeping worldwide (Sammataro et al., 2000). This highly specialized parasite of the honeybee feeds on both the brood and the adult bee, and reproduces in the brood cell. Although the mite causes little damage to its original host, the Asian honeybee Apis cerana, it is lethal for European A. mellifera colonies to which it transferred more than 30 years ago (Matheson, 1995). Therefore, adequate and timely mite control is essential for apiculture in Europe and most other regions of the world. Varroa mite control is overwhelmingly based on chemicals that typically end up as residues in honey and other bee products (Bogdanov, 2006). Even so, several tiny populations of European honeybees survive sustainably with Varroa mites without chemical control (Nordström et al., 1999; Fries et al., 2006a; Fries and Bommarco, 2007; Le Conte et al., 2007; Büchler et al., 2010; Le Conte et al., 2010). There are also several European honeybee populations that have never been infested by mites, such as on the Island of Ouessant in France, large parts of northern Sweden and the Finnish island Aland in the Baltic Sea. Such populations are essential for understanding the genetic mechanisms driving mite infestation tolerance (for the Varroa-tolerant feral colonies) and the epidemiological and evolutionary mechanisms underlying the lethal interactions between Varroa and viral pathogens (for the Varroa-free populations). There are similar populations elsewhere (Australian Varroa-free populations; African and South American Varroa-tolerant populations) for comparison with European populations.

\subsubsection{Nosema spp.}

Nosema fungi are wide-spread microsporidian gut parasites of adult honeybees. They infect host mid-gut epithelial cells and deteriorate the metabolic processes of infected bees (Fries, 1988, 1993). Currently, two different Nosema species have been reported in $A$. mellifera: $N$. apis, a well established pathogen of A. mellifera with moderate virulence that does not usually cause lethal infections, and $N$. ceranae, thought to be originally a parasite of the Asian honeybee A. cerana, which has recently been introduced into European honeybee populations (Fries et al., 1996, 2006b; Paxton et al., 2007; Chen et al., 2008) and distributed by apicultural trade across the globe (Klee et al., 2007). It is now present in all continents except Antarctica (Klee et al., 2007; Higes et al., 2009) and honeybees can be co-infected with both Nosema species. N. ceranae infestations appear to be more severe in southern than in northern parts of Europe (Fries, 2010). Moreover, N. ceranae seems to replace $N$. apis worldwide (Klee et al., 
2007) although it does not appear to have a competitive advantage within an individual host bee (Forsgren and Fries, 2010).

In Spain, $N$. ceranae has been reported to be linked to the sudden collapse of A. mellifera colonies (Higes et al., 2008) and increased risk of colony death if not actively controlled (Martín-Hernández et al., 2007). This high colony level virulence of $N$. ceranae in Spain may be a regional phenomenon, as high colony mortality is not always observed (Siede et al., 2008; Invernizzi et al., 2009). Moreover, several viruses are associated with Nosema infections that can significantly affect the apparent virulence of Nosema (Bailey and Ball, 1991). Very little study has so far been dedicated to these potentially important interactions, which European research strategies aim to address. Due to the similarity in life histories of the two Nosema spp., it is likely that the interactions with other factors may be similar for $N$. apis and $N$. ceranae. The $N$. apis genome is currently being sequenced (J. Evans, unpubl. data; Chen and Huang, 2010) which will greatly facilitate its study.

\subsection{Viral pathogens}

At least 18 viruses have been identified that affect brood and/or adult honeybees (Bailey and Ball, 1991; Ribière et al., 2008). Even healthy colonies are usually covertly infected by several viruses (Tentcheva et al., 2004). V. destructor has been shown to be an important vector for several of these viruses. Likewise, a number of viruses seem to be closely linked to Nosema infections. Since the large number of viruses affecting bees renders it impossible to run full factorial experimental designs on all possible interactions, it is will be more meaningful to focus on the best established and most dramatic virus-parasite interactions. Once these interactions are understood, other viruses can perhaps also be assessed, though currently only from correlational evidence from large scale field data to understand their impact on colony health.

\subsubsection{Deformed Wing Virus (DWV)}

DWV is by far the most widespread honeybee virus (Ribière et al., 2008; de Miranda and Genersch, 2010) due to its close association with V. destructor (Bowen-Walker et al., 1999; Tentcheva et al., 2006; Gauthier et al., 2007). DWV became almost ubiquitous throughout Europe with the spread of Varroa (Allen and Ball, 1996). Of itself, DWV is one of the least virulent of bee viruses and its damage to individual bees and colonies is only due to its relationship with Varroa mites. It has been shown to be transmitted by, and to replicate inside $V$. destructor (Ongus et al., 2004; Yue and Genersch, 2005). Furthermore, DWV symptoms in emerging bees appear to be related to virus replication in the infesting mites during the pupal phase (Yue and Genersch, 2005; Gisder et al., 2009). The paradox of the DWV - Varroa - bee interaction is that it is precisely the low virulence of DWV that allows Varroa infested pupae to complete development despite the virus infection, thus liberating the reproducing mites and sustaining the Varroa DWV epidemic that ultimately becomes lethal at colony level (Sumpter and Martin, 2004). This contrast between individual and colonylevel virulence is also seen with other bee pathogens, emphasizing the need to study such interactions at both levels.

\subsubsection{Black Queen Cell Virus (BQCV)}

BQCV itself is not particularly damaging. However, it has a synergistic effect with Nosema infections, making the latter more harmful (Bailey et al., 1981, 1983). Recent surveys show it to be present in about $30 \%$ of colonies in France and central Europe (Tentcheva et al., 2004; Berényi et al., 2006; Gauthier et al., 2007) making it a significant virus. Although BQCV is named for its effect on queen pupae, it is primarily distributed in adult bees (Tentcheva et al., 2004) which is also the only stage known to be affected by Nosema (Fries, 1988, 1993). BEE DOC will focus on this virus-endoparasite combination to test for interaction mechanisms occurring at the adult stages of the bee. 


\subsubsection{Israel Acute Paralysis Virus (IAPV)}

IAPV is part of a larger species complex (de Miranda et al., 2010) that also includes Kashmir Bee Virus (KBV) and Acute Bee Paralysis Virus (ABPV), two viruses that can be lethal at individual bee and colony levels (Todd et al., 2007; Ball and Allen, 1988). IAPV has been considered an associative factor for Colony Collapse Disorder (CCD) in America (Cox-Foster et al., 2007; Johnson et al., 2009). In the past, European colony losses with symptoms similar to CCD have been associated with ABPV (Berényi et al., 2006). Although the significance of IAPV for CCD is still unclear (Oldroyd, 2007; Stokstad, 2007; Anderson and East, 2008), it is sensible to include this virus complex at the experimental level to clarify its importance for European honeybee populations, including the possible interchangeability of IAPV, KBV and ABPV as risk indicators for colony collapse in different geographic areas (de Miranda et al., 2010).

\subsection{Bacterial pathogens}

American foulbrood (AFB) is caused by the spore-forming bacterium Paenibacillus larvae and is the most significant bacterial disease in apiculture. Although this disease was identified $>100$ years ago, it still plagues beekeeping in the EU. On a global scale, antibiotic treatment for AFB is standard, although less common in Europe. Employing selection for resistant honeybee strains has had priority in breeding work for many years, as has the disruption of infection pathways as tools to develop contamination-free remedy schemes. Clearly, the prime goal is to make antibiotic treatments obsolete. Not only do as they inevitably lead to honey contamination and pathogen resistance (Spivak, 2001), but they will most likely also kill the beneficial honeybee probiotic microflora that is part of the natural honeybee defence against AFB (Forsgren et al., 2009; Yoshiyama and Kimura, 2009). Although there is wide variation in virulence between P. larvae strains, the most virulent strains at the individual larval level are the least virulent strains at the colony level (Genersch et al., 2005), since the larvae die and are removed by hygienic behaviour before spore production can be maximised. It is therefore essential to combine individual and colony level studies to determine the significance of virulence and transmission for the epidemiology of AFB. This information is essential for developing management and selection programmes for disease control (Dieckmann et al., 2000).

\subsection{Pesticides}

\subsubsection{Lethal and sublethal}

The honeybee is unusually sensitive to a range of chemical insecticides (Stefanidou et al., 2003; Thompson, 2003; Barnett et al., 2007), most likely due to a relative deficit of detoxification enzymes (Yu et al., 1984; Claudianos et al., 2006). Foraging bees can encounter lethal pesticide levels when foraging but they can also bring back contaminated nectar and pollen to the hive. In addition to the pesticides the bees are exposed to during foraging, beekeepers also use various acaricides to control mite infections, particularly $V$. destructor (Sammataro et al., 2000). Most of these are lipophilic and accumulate in the wax, increasingly contaminating the combs where the brood develops. More importantly, nothing is known about the interactions between agricultural pesticides foraged on by bees, the acaricides applied by the beekeeper, and pests and pathogens.

The EU directive 91/414 Section 2.5.3 regulates the use of pesticides in the context of apiculture. "...no authorization will be granted if the hazard quotients for oral or contact exposure of honeybees are greater than 50, unless it is clearly established through appropriate risk assessment that under field conditions there are no unacceptable effects on honeybee larvae, honeybee behaviour, or colony survival and development after the use of plant protections product according to he proposed conditions of use". Acute mortality can occur and its diagnosis is usually easily established by the presences of many dead bees in front of the hive. However, honeybees can also encounter sub-lethal effects of pesticides that are 
much more difficult to detect since they affect longevity or behaviour. Such sub-lethal effects can cause disruptions in social interactions that are essential for colony function (Weick and Thorn, 2002). Since many pathogens have similar sub-lethal effects on longevity and behaviour (Ball and Bailey, 1991), the cumulative impact of different sub-lethal effects may be significant at colony level, even when they are not immediately apparent when studied in isolation, and at individual bee level.

The huge suite of agro-chemicals currently used in agriculture makes it clearly impossible to run full factorial design experiments testing the effects and interactions of all of those compounds. If we focus on selected model compounds we will be able to extract the principle effects of the pesticide interactions with parasites and pathogens on colony health. For example the BEE DOC research network will focus only on two major compounds, one neonicotinoid agro-pesticide, thiacloprid, and one pyrethroid acaricide, $\tau$-fluvalinate. Thiacloprid and $\tau$-fluvalinate therefore represent the two most important and common pesticide groups (pyrethroids and neonicotinoids) with different modes of action on the target organisms.

\subsubsection{Thiacloprid}

Thiacloprid is a broad-spectrum neonicotinoid insecticide with a fairly low acute bee toxicity, and is used against a wide range of lepidopteran, coleopteran and orthopteran crop pests, including oil seed rape and fruit orchards which are crops intensively used by honey bees. Consequently, the active ingredient is commonly found in the hive and in pollen pellets of foragers (Chauzat et al., 2006; Chauzat and Faucon, 2007).

\subsection{3. $\tau$-fluvalinate}

$\tau$-fluvalinate is a pyrethroid used to control a broad range of pests including moths, aphids, thrips and leafhoppers. It is also used widely to control the mites in beekeeping, and accumulates in the wax of the comb at high concentrations (Bogdanov et al., 1998; Wallner,
1999; Tremolada et al., 2004). It is one of the most common pesticides found in honeybee colonies.

\section{TOOLS AND CONCEPTS TO IMPROVE COLONY HEALTH}

\subsection{Probiotic bacteria}

Bifidobacterium and lactic acid bacteria (LAB) from the genus Lactobacillus are generally beneficial bacterial species. They are part of the natural gastrointestinal flora of healthy animals and are sold commercially as probiotics, live micro-organisms, that confer health benefits to their host. The honeybee also has a unique honey stomach probiotic flora involving Lactobacillus and Bifidobacterium bacteria (Olofsson and Vasquez, 2008; Yoshiyama and Kimura, 2009) that protects the bee from harmful micro-organisms in exchange for a nutrient rich niche. LAB produce such antibacterial compounds as organic acids, hydrogen peroxide, diacetyl, benzoate, and bacteriocins, all of which are beneficial for humans and animals (Coenye and Vandamme, 2003; Ouwehand et al., 2002) and presumably for honeybees as well. Most interestingly, LAB have recently been shown to strongly inhibit P. larvae, the bacterium causing American Foulbrood (Forsgren et al., 2009).

\subsection{Plant and honeybee derived compounds}

Apiary hygiene alone is insufficient for disease control and prevention, and persistent and prophylactic chemical treatments inevitably lead to pathogen resistance (Lodesani, 1995; Milani, 1995, 1999; Elzen, 1998; Thompson, 2002). European research strategies will therefore include a focus on the development of novel treatments by using therapies designed by nature and by the honeybees themselves. Compounds from propolis collected by bees will be tested for their impact on disease control and prevention. Also honeybee-produced peptides will be produced by recombinant technology with the goal of 
applying them to the colony for disease treatment. The honeybee colony is armed against pathogens with a very effective exogenous defense system based on the multi-functionality of nutritive proteins and antimicrobial phytochemicals. These compounds are present in nectar, pollen and propolis and have proven to be effective acaricides and antimicrobial agents in many organisms, including humans (Bankova et al., 1995; Gil et al., 2000; TomásBarberán and Wollenweber, 1990; TomásBarberan et al., 1989; Popova et al., 2004, 2007; Bankova, 2005). Paradoxically, little information is available about the efficacy of these compounds against honeybee parasites and pathogens. In particular propolis is considered to be the most important chemical defense mechanism of honeybees against microorganisms, since it is based on metabolites used by plants against pests and diseases (e.g., Simone et al., 2009; Simone and Spivak, 2010). Honeybees also have innate molecular defenses against pathogens, such as antimicrobial peptides and nucleic acids, whose activity can be stimulated by appropriate molecular therapies. Propolis constituents, recombinant honeybee peptides, and molecular therapies will be assayed at individual and colony level, singly and in combination, for efficacy against honeybee diseases.

To control diseases efficiently with novel, sustainable strategies, we must understand the infection processes at all relevant levels: from the apiary, via the colony and individual bee, down to the molecular immune mechanisms at the genome level. The interactions among pathogens driving virulence and transmission of diseases need to be comprehensively understood if we want to design more efficient treatments that are also effective at the population level (Evans and Spivak, 2010). We will need to develop strategies that not only increase bee tolerance to specific diseases, but those that can reduce pathogen virulence by blocking critical infection pathways or harmful interactions among pathogens. This will enable the development of complementary strategies for disease control to prevent colony losses and secure the quality and safety of honey and other bee products.

\subsection{Disease resistance genetics and genomics}

In an ideal beekeepers' world, honeybees should not require any treatment against diseases at all, which would prevent the contamination of colonies with in-hive chemicals used in apicultural management. EU research therefore focuses on the identification of genes that regulate resistance towards Varroa and American Foulbrood. In the context of the BEE DOC network, the immune system of honeybees lies at the centre of interest because the responses of the bees towards virus infections need to be addressed. Although A. mellifera lacks about $30 \%$ of immune system genes that are known from different dipteran species (e.g. Drosophila melanogaster, Anopheles gambiae), the three basic immune pathways - the Toll-, IMD- and JAK/STAT-pathway have been identified in the honeybee genome (Evans et al., 2006). One argument for the deficit of immune genes was that colony level pathogen resistance mechanisms would be more important in social insects compared to solitary insects. However, individual resistance mechanisms are equally essential in a social context as in the solitary one. It is therefore likely that the gene cascades in these pathways are differently regulated compared to the other insect model systems, yielding similar results yet in a colony context. In this context, it may be highly rewarding to compare genes identified in the honeybee with homologues in the well studied fruit fly Drosophila. There are even reports of a specific memory in insect immune systems (Kurtz and Franz, 2003), albeit with a lower adaptability compared to vertebrate immune systems. Hence, we expect to find very specific modifications of the already known immune gene cascades for evolutionary stable insect host parasite systems, and also highly species specific, yet unknown, mechanisms for controlling the pathogen resistance of bees. Since oligonucleotide microarrays with all annotated genes of the honeybee ( 13400 genes) are available, the transcriptome can be screened to reveal differential genome responses to specific infections. Although such studies cannot identify the function of novel honeybee 
specific genes, they can reveal the function of gene cascades in response to various environmental conditions (Grozinger et al., 2003) including bee health stressors (Navajas et al., 2008), which are essential to understand gene control of the phenotype.

\subsubsection{Candidate genes known from sequence homology}

Genes already known from model organisms can be identified by standard bioinformatics: those specific for honeybees still require mapping and gene expression studies. This is greatly facilitated with the complete genome sequence for the honeybee at hand. For example the gene "thelytoky" (th) was mapped down to $20 \mathrm{cM}$ within a few months and was recently identified as a transcription factor homologous to gemini in Drosophila (Lattorff et al., 2007). Two genes, th and csd (the sex locus), are currently the only two known honeybee specific genes. This may seem to be a low number of genes, but only in a few cases will a single gene determine a specific phenotype. Most phenotypes will be controlled by several genes, so called quantitative trait loci (QTL). If there are only few major QTLs for a trait these can be mapped by testing linkage with segregation of a large number of variable markers (e.g. microsatellite markers) which saturate the genome. Because the recombination rate of the honeybee genome is $19 \mathrm{cM} / \mathrm{Mb}$, an order of magnitude higher than in Drosophila, honeybee mapping studies require a large number of marker loci to saturate the genome (Weinstock et al., 2006). For gene identification, the high recombination rate is an advantage, because linked markers can be physically very close to a target gene. Once a genomic region with a QTL has been identified, the sequence allows for saturating this target region with a large number of novel microsatellite markers for fine mapping. Comparisons across microarray experiments show differential transcriptome responses towards infestations with Varroa (Navajas et al., 2008). The novel oligonucleotide microarray comprising all annotated 13440 genes of the honeybee has already been validated and found to be most informative (Kocher et al., 2008; Alaux et al., 2009). With this tool the genomic responses towards pathogens and pesticides at the transcriptome level can be used to explore host-pathogen interactions at the molecular level.

\subsubsection{Novel genes specific to honeybees}

In addition, it will be important to identify novel genes that control host - pathogen interactions. Many pathogens are highly specific to the honeybee system and hence very special solutions for pathogen resistance may have evolved. A key element will be to use drones for mapping of quantitative trait loci (QTL) that are relevant for disease resistance (Moritz and Evans, 2007). Candidate loci for all brood diseases including AFB susceptibility, Varroa resistance, DWV resistance and Nosema resistance will need to be identified. This will complete the set of resistance genes to the main honeybee diseases, which will greatly facilitate breeding programs.

\subsection{Diagnostics}

The different operational levels of BEE DOC (experimental, surveillance, applied) require different tools for identifying the various parasites, pathogens and chemicals. This internal requirement will allow BEE DOC to provide diagnostic tools to different groups of stakeholders in the bee industry, from the researcher to the beekeeper.

\subsubsection{Experimental}

Real time RT-qPCR is the standard technique for quantitative diagnosis of the bee pathogens. Microarrays (Navajas et al., 2008; Johnson et al., 2009), metagenomic analyses (Cox-Foster et al., 2007) and next generation DNA sequencing are more comprehensive (and expensive) screening technologies, to be used only in limited experimental setting. DNA chip technology (Whitfield et al., 2006) allows a rapid yet cost efficient diagnosis of all 
known pathogens in experimental samples, as well as a number of honeybee genes of interest (Evans, 2007). Pesticides and bio-chemicals will be quantified by a number of chromatographic techniques.

\subsubsection{Surveillance}

The real-time quantitative PCR-based diagnostic tools for pathogen detection, as well as the pesticide and biochemical analyses, will be adapted for routine use in large-scale surveys by extension labs.

\subsubsection{Applied}

Robust, immunochromatography-based stick assays, common in medical and veterinary disease diagnosis (Abhyankar et al., 2006; Pugia et al., 2004), will need to be developed to facilitate accurate, sensitive and instant diagnosis of honeybee diseases in the field.

\section{IMPLEMENTION OF SCIENTIFIC PROGRESS INTO APICULTURAL PRACTICE AND COORDINATION OF RESEARCH}

The transfer from science into application is typically a major problem. In Europe this transfer is greatly facilitated through one of the largest programs in history, COST (European COoperation in Science and Technology). COLOSS (Prevention of Honeybee Colony Losses, http://www.coloss.org/) is a global network with currently over 150 partners in 39 countries (most of Europe, Australia, Canada, Israel, Jordan, PR China, South Korea, Republic of South Africa, USA). The aim of COLOS is to coordinate national and international efforts to explain and prevent large scale losses of honeybee colonies. For that purpose, international standards will be developed for both monitoring and research activities in form of a BEE BOOK (analogous to the RED BOOK of the Drosophila community). This effort will enable combined and large-scale international research efforts to identify the underlying factors and mechanisms (e.g. ring tests). Indeed, efforts by individual countries to reveal the drivers of colony losses have small chance of success due to the high number of interacting factors. Therefore, the development of emergency measures and sustainable management strategies will require an international network. The COLOSS network does not directly support science but aims at coordinating national research activities across Europe and the world. COLOSS comprises all three groups of stakeholders, scientists, beekeepers and industry with the aims of complementing and not duplicating research approaches, and of creating trans-national synergies. The tight networking among science and the industry is facilitated through conferences, and more importantly, through a large series of hands-on workshops for extension specialists and apiculturists. The European and global strategy for the prevention of colony losses is therefore clearly based on a broad transnational platform with a strong focus on the transfer of science into practice. Only if we succeed to bridge the gap between bee scientists and apiculture will we achieve sustainable progress in the prevention of colony losses at a continental scale.

\section{ACKNOWLEDGEMENTS}

Funding for the BEE DOC research network has been provided by the EU Commission (RTD REG/E.4(2009)D/561221) and for the COLOSS network by the COST action FA0803. Stratégies de recherche pour améliorer la santé
des abeilles en Europe.

Apis mellifera / pathologie / diagnostic / résistance aux maladies

Zusammenfassung - Forschungsstrategien zur Verbesserung der Bienengesundheit in Europa. Die letzten Jahrzehnte waren durch einen konstanten Rückgang von Bienenvölkern in den Mitgliedstaaten der EU gekennzeichnet (cf. Abb. 1). Insbesondere dramatische und unkontrollierbare Völkerverluste entwickelten sich zu einer akuten Insolvenz - Bedrohung für Imkereibetriebe. Nach wie vor sind die Ursachen dieser großen, flächendeckenden Völkerverluste auf nationaler 
Ebene unklar und daher sind zielgerichtete kausale Therapien nicht möglich. Oft wurden daher unnötige, prophylaktisch medikamentöse Behandlungen durchgeführt, um regionale Völkerbestände $\mathrm{zu}$ sichern. Dies hat bislang jedoch noch nicht zu einer nachhaltigen Bekämpfung von Bienenkrankheiten geführt, allerdings regelmäßig zur Kontamination des Honigs.

Die Forschungspolitik der EU zielt daher darauf ab, die Honigbelastung zu reduzieren, die Rassevielfalt europäischer Honigbienen zu erhalten, Völkerverluste $\mathrm{zu}$ vermeiden und die Bedeutung der Interaktionen zwischen Parasiten, Pathogenen und Pestiziden für die Koloniegesundheit zu verstehen. Gerade die Kombination verschiedener Faktoren wird als ein besonderes Problem gesehen. Eine einzelnes Pathogen mag für die Kolonie harmlos sein, aber in Kombination mit anderen zum Zusammenbruch des Volkes führen.

Das Forschungsnetzwerk BEE DOC (Bees in EuropE and the Decline Of Honeybee Colonies) wird sich deshalb mit den Interaktionen zwischen Parasiten, Pathogenen und Pestiziden beschäftigen. In Anbetracht der großen Zahl von Pathogenen und Pestiziden ist es allerdings nicht realisierbar, alle möglichen Interaktionen experimentell $\mathrm{zu}$ testen. Es ist daher notwendig, sich in Experimenten auf wenige ausgewählte Modellsysteme von besonderer Bedeutung zu beschränken. Im BEE DOC Netzwerk sind dies $V$. destructor, Nosema spp., häufige assoziierte Viren, und die häufig genutzten Pestizide Thiacloprid und $\tau$-Fluvalinat. Die Forschungsaktivitäten müssen auch die Untersuchung der genetischen und genomischen Kontrolle von Krankheitsresistenz beinhalten. Oligonukleotid DNA-Chips die das gesamte Genom der Honigbiene abdecken sind dabei von besonderem Nutzen. Zusätzlich sollen neue Resistenzgene mit Hilfe von haploiden Drohnen gefunden werden. Antibiotische Substanzen, die entweder von den Bienen selbst erzeugt oder von Pflanzen gesammelt werden sollen auf ihre Wirksamkeit bei der Bekämpfung von Bienenkrankheiten untersucht werden. Gerade sekundäre Metabolite von Pflanzensubstanzen, die von der Honigbeine enzymatisch verändert wurden um eine höhere Wirksamkeit zu erhalten, sind von besonderem Interesse. Neue diagnostische Verfahren, die in der Forschung, im Routine screening und auf dem Bienenstand eingesetzt werden können müssen entwickelt werden, um rechtzeitig Erkrankungen bei den Bienenvölkern diagnostizieren zu können bevor diese zusammenbrechen.

Der Erfolg dieser Forschungsarbeiten wird stark von Koordinierung des Monitoring und der Forschung sowie von der Implementierung der Ergebnisse in die imkerliche Praxis abhängig sein. Das COLOSS Netzwerk (Cost Action) ist hierfür in den nächsten Jahren ein hervorragendes Werkzeug. In ihm sind über 150 Mitglieder aus 39 Ländern vertreten, die die nationalen Forschungs- projekte zur Bienengesundheit koordinieren und aufeinander abstimmen. Nur wenn es gelingt, die Forschungsergebnisse in der Imkerei umzusetzen, werden wir Fortschritte bei der nachhaltigen Prävention von Völkerverlusten auf einer europaund weltweiten Ebene erzielen können.

\section{Apis mellifera / Pathologie / Diagnose / Krank- heitsresistenz}

\section{REFERENCES}

Abhyankar A.V., Dash P.K., Saxena P., Bhargava R., Parida M.M., Jana A.M., Sahni A.K., Rao P.V.L. (2006) Comparison of a dipstick dot-ELISA with commercial assays for anti-dengue virus IgM antibodies, Viral Immunol. 19, 630-636.

Alaux C., Le Conte Y., Adams, H.A., RodriguezZas S., Grozinger C.M., Sinha S., Robinson G.E. (2009) Regulation of brain gene expression in honey bees by brood pheromone, Gene Brain Behav. 8, 309-319.

Allen M.F., Ball B.V. (1996) The incidence and world distribution of honey bee viruses, Bee World 77, 141-162.

Anderson D., East I.J. (2008) The latest buzz about colony collapse disorder, Science 319, 724-725.

Bailey L., Ball B.V. (1991) Honey bee pathology, 2nd ed., Academic Press, London.

Bailey L., Ball B.V., Perry J.N. (1981) The prevalence of viruses in Britain, Ann. Appl. Biol. 97, 109118.

Bailey L., Ball B.V., Perry J.N. (1983) Association of viruses with 2 protozoal pathogens of the honeybee, Ann. Appl. Biol. 103, 13-20.

Ball B.V., Allen M.F. (1988) The prevalence of pathogens in honey bee (Apis mellifera) colonies infested with the parasitic mite Varroa jacobsoni, Ann. Appl. Biol. 113, 237-244.

Bankova V. (2005) Recent trends and important developments in propolis research, Evidence Based Complement Alternat. Med. 2, 29-32.

Bankova V., Christov R., Kujumgiev A., Marcucci M.C., Popova S. (1995) Chemical Composition and antibacterial activity of Brazilian propolis, $\mathrm{Z}$. Naturforsch. c 50, 167-172.

Barnett E.A. Charlton A.J., Fletcher M.R. (2007) Incidents of bee poisoning with pesticides in the United Kingdom, 1994-2003, Pest Manag. Sci. 63, 1051-1057.

Benjamin A., McCallum B. (2008) A world without bees, Guardian books.

Berényi O., Bakonyi T, Derakhshifar I, Koglberger H, Nowotny N. (2006) Occurrence of six honeybee viruses in diseased Austrian apiaries, Appl. Environ. Microb. 72, 2414-2420. 
Bogdanov S. (2006) Contaminants of bee products, Apidologie 37, 1-18.

Bogdanov S., Imdorf A., Kilchenmann V. (1998) Acaricide residues in some bee products, J. Apic. Res. 37, 57-67.

Bowen-Walker P.L., Martin S.J., Gunn A. (1999) The transmission of deformed wing virus between honeybees (Apis mellifera L.) by the ectoparasitic mite Varroa jacobsoni Oud., J. Invertebr. Pathol. 73, 101-106.

Büchler R., Berg S., Le Conte Y. (2010) Breeding for mite resistance in Europe, Apidologie 41, 393408.

Chauzat M.P., Faucon J.P. (2007) Pesticide residues in beeswax samples collected from honey bee colonies (Apis mellifera L.) in France, Pest Manag. Sci. 63, 1100-1106.

Chauzat M.P., Faucon J.P., Martel A.C., Lachaize J., Cougoule N., Aubert M. (2006) A survey of pesticide residues in pollen loads collected by honey bees in France, J. Econ. Entomol. 99, 253-262.

Chen Y., Evans J.D. (2007) Historical presence of Israeli Acute Paralysis Virus in the United States, Am. Bee J. 147, 1027-1028.

Chen Y.P., Huang Z.Y. (2010) Nosema ceranae, a newly identified pathogen of Apis mellifera in the U.S.A. and Asia, Apidologie 41, 364-374.

Chen Y., Evans J.D., Feldlaufer M. (2005) Detection of multiple viruses in queens of the honey bee Apis mellifera L., J. Invertebr. Pathol. 90, 118-121.

Chen Y., Evans J.D., Feldlaufer M. (2006) Horizontal and vertical transmission of viruses in the honeybee, Apis mellifera, J. Invertebr. Pathol. 92, 152159.

Chen Y., Evans J.D., Smith I.B., Pettis J.S. (2008) Nosema ceranae is a long-present and widespread microsporidian infection of the European honey bee (Apis mellifera) in the United States, J. Invertebr. Pathol. 97, 186-188.

Claudianos C., Ranson H., Johnson R.M., Biswas S., Schuler M.A, Berenbaum M.R., Feyereisen R., Oakeshott J.G. (2006) A deficit of detoxification enzymes: pesticide sensitivity and environmental response in the honeybee, Insect Mol. Biol. 15, 615-636.

Coenye T., Vandamme P. (2003) Extracting phylogenetic information from whole-genome sequencing projects: the lactic acid bacteria as a test case, Microbiol SGM 149, 3507-3517.

Cox-Foster D.L., Conlan S., Holmes E.C. et al. (2007) A metagenomic survey of microbes in honey bee colony collapse disorder, Science 318, 283-287.

Dainat B., Ken T., Berthoud H., Neumann P. (2009) The ectoparasitic mite Tropilaelaps mercedesae (Acari, Laelapidae) as a vector of honeybee viruses, Insectes Soc. 56, 40-43.

de Jong D., Morse R.A., Eickwort G.C. (1982) Mite pests of honeybees, Annu. Rev. Entomol. 27, 229252. de Miranda J.R., Cordoni G., Budge G. (2010) The acute bee paralysis virus - Kashmir bee virus - Israeli paralysis virus complex, J. Invertebr. Pathol. 103, S30-S47.

de Miranda J.R., Genersch E. (2010) Deformed wing virus, J. Invertebr. Pathol. 103, S48-S61.

Delaplane K.S., Mayer D.F. (2000) Crop pollination by bees, CAB, New York.

Dieckmann U., Metz J.A.J., Sabelis M.W., Sigmund K. (2000) Adaptive dynamics of infectious diseases: in pursuit of virulence management, Cambridge University Press, Cambridge.

Ellis J.D., Munn P.A. (2005) The worldwide health status of honey bees, Bee World 86, 88-101.

Elzen P.J. (1998) Fluvalinate resistance in Varroa jacobsoni from several geographic locations, Am. Bee J. 138, 6741998.

Evans J.D. (2007) Bee Path: An Ordered QuantitativePCR Array for Honey Bee Immunity and Disease, J. Invertebr. Pathol. 93, 135-139.

Evans J.D., Spivak M. (2010) Socialized medicine: Individual and communal disease barriers in honey bees, J. Invertebr. Pathol. 103, S62-S72.

Evans J.D., Aronstein K., Chen Y., Hetru C., Imler J.-L., Jiang H., Kanost M., Thompson G.J., Zou Z., Hultmark D. (2006) Immune pathways and defence mechanisms in honey bees Apis mellifera, Insect Mol. Biol. 15, 645-656.

Eyer M., Chen Y.P., Schäfer M.O., Pettis J.S., Neumann P. (2009) Small hive beetle, Aethina tumida, as a potential biological vector of honeybee viruses, Apidologie 40, 419-428.

Faucon J.P., Mathieu L., Ribiere M., Martel A.C., Drajnudel P., Zeggane S., Aurieres C., Aubert M.F.A. (2002) Honey bee winter mortality in France in 1999 and 2000, Bee World 83, 14-23.

Flemming G. (1871) Animal plagues, Their history, nature and prevention, Chapman \& Hall.

FAO (2009) FAOSTAT/Production/Live Animals, http://faostat.fao.org.

Forsgren E., Fries I. (2010) Comparative virulence of Nosema ceranae and Nosema apis in individual European honey bees, Vet. Parasitol., in press.

Forsgren E., de Miranda J.R., Isaksson M., Wei S., Fries I. (2009) Deformed wing virus associated with Tropilaelaps mercedesae infesting European honey bees (Apis mellifera), Exp. Appl. Acarol. 47, 87-97.

Forsgren E., Olofsson T., Vásquez A. (2009) Novel Lactic Acid Bacteria inhibiting Paenibacillus larvae in honey bee larvae, Apidologie 41, 99-108.

Fries I. (1988) Infectivity and multiplication of Nosema apis Z. in the ventriculus of the honeybee, Apidologie 19, 319-328.

Fries I. (1993) Nosema apis - a parasite in the honeybee colony, Bee World 74, 5-19.

Fries I. (2010) Nosema ceranae in European honey bees (Apis mellifera), J. Invertebr. Pathol. 103, S73-S79. 
Fries I., Bommarco R. (2007) Possible host-parasite adaptations in honey bees infested by Varroa destructor mites, Apidologie 38, 525-533.

Fries I., Feng F., daSilva A., Slemenda S.B., Pieniazek N.J. (1996) Nosema ceranae n. sp. (Microspora, Nosematidae), morphological and molecular characterization of a microsporidian parasite of the Asian honey bee Apis cerana (Hymenoptera, Apidae), Eur. J. Protistol. 32, 356-365.

Fries I., Imdorf A., Rosenkranz P. (2006a) Survival of mite infested (Varroa destructor) honey bee (Apis mellifera) colonies in a Nordic climate, Apidologie 37, 564-570.

Fries I., Martin R., Meana A., Garcia-Palencia P., Higes M. (2006b) Natural infections of Nosema ceranae in European honey bees, J. Apic. Res. 45, 230-233.

Gallai N., Salles J.-M., Settele J., Vaissière B.E. (2008) Economic valuation of the vulnerability of world agriculture confronted with pollinator decline, Ecol. Econom. 68, 810-821.

Gauthier L., Tentcheva D., Tournaire M., Dainat B., Cousserans F., Colin M.E., Bergoin M. (2007) Viral load estimation in asymptomatic honey bee colonies using the quantitative RT-PCR technique, Apidologie 38, 426-435.

Genersch E., Ashiralieva A., Fries I. (2005) Strainand genotype-specific differences in virulence of Paenibacillus larvae subsp. larvae, a honeybee bacterial pathogen causing American foulbrood disease, Appl. Environ. Microbiol. 71, 75517555.

Genersch E., von der Ohe W., Kaatz H., Schroeder A., Otten C., Büchler R., Berg S., Ritter W., Mülhen W., Gisder S., Meixner M., Liebig G., Rosenkranz P. (2010) The German Bee Monitoring Project: a long term study to understand periodically high winter losses of honey bee colonies, Apidologie 41, 332-352.

Gil M.I., Tomas-Barberan F.A., Hess-Pierce B., Holcroft D.M., Kader A.A. (2000) Antioxidant activity of pomegranate juice and its relationship with phenolic composition and processing, J. Agric. Food Chem. 48, 4581-4589.

Gisder S., Aumeier P., Genersch E. 2009. Deformed wing virus (DWV): viral load and replication in mites (Varroa destructor), J. Gen. Virol. 90, 463467.

Grozinger C.M., Sharabash N.M., Whitfield C.W., Robinson G.E. (2003) Pheromone-mediated gene expression in the honey bee brain, Proc. Natl. Acad. Sci. USA 100, 14519-14525.

Higes M., Martin-Hernandez R., Botias C., Garrido Bailon E., Gonzalez-Porto A.V., Barrios L., del Nozal M.J., Bernal J.L., Jimenez J.J., Palencia P.G., Meana A. (2008) How natural infection by Nosema ceranae causes honeybee colony collapse, Environ. Microbiol. 10, 2659-2669.

Higes M., Martin-Hernandez R., Garrido-Bailon E., Botias C., Meana A. (2009), The presence of
Nosema ceranae (Microsporidia) in North African honey bees (Apis mellifera intermissa), J. Apic. Res. 48, 217-219.

Hung A.C.F., Adams J.R., Shimanuki H. (1995) Bee parastic mite syndrome. 2. the role of Varroa mite and viruses, Am. Bee J. 135, 702-704.

Invernizzi C., Abud C., Tomasco I.H., Harriet J., Ramallo G., Campa J., Katz H., Gardiol G., Mendoza Y. (2009) Presence of Nosema ceranae in honeybees (Apis mellifera) in Uruguay, J. Invertebr. Pathol. 101, 150-153.

Jaffé R., Dietemann V., Allsopp M.H., Costa C., Crewe R.M., Dall' Olio R., De La Rua P., El-Niweiri M.A.A., Fries I., Kezic N., Meusel M.S., Paxton R.J., Shaibi T., Stolle E., Moritz R.F.A. (2009) Estimating the density of honeybee colonies across their natural range to fill the gap in pollinator decline censuses, Conserv. Biol., DOI: 10.1111/j.1523-1739.2009.01331.x.

Johnson R.M., Evans J.D., Robinson G.E., Berenbaum M.R. (2009) Changes in transcript abundance relating to colony collapse disorder in honey bees (Apis mellifera), Proc. Natl. Acad. Sci. USA 106, 14790-14795.

Klee J., Besana A.M.., Genersch E., Gisder S., Nanetti A., Tam D.Q., Chinh T.X., Puerta F., Ruz J.M., Kryger P., Message D., Hatjina F., Korpela S., Fries I., Paxton R.J. (2007) Widespread dispersal of the microsporidian Nosema ceranae, an emergent pathogen of the western honey bee, Apis mellifera, J. Invertebr. Pathol. 96, 1-10.

Kocher S.D., Richard F.-J., Tarpy D.R., Crozinger C.M. (2008) Genomic analysis of post-mating changes in the honey bee queen (Apis mellifera), BMC Genomics 9, e232.

Kraus B., Page R.E. (1995) Effect of Varroa jacobsoni (Mesostigmata: Varroidae) on feral Apis mellifera (Hymenoptera: Apidae) in California, Environ. Entomol. 24, 1473-1480.

Kurtz J., Franz K. (2003) Evidence for memory in invertebrate immunity, Nature 425, 37-38.

Lattorff H.M.G., Moritz R.F.A., Crewe R.M., Solignac M. (2007) Control of reproductive dominance by the thelytoky gene in honeybees, Biol. Lett. 3, 292-295.

Le Conte Y., De Vaublanc G., Crauser D., Jeanne F., Rousselle J.-C., Becard J.-M. (2007) Honey bee colonies that have survived Varroa destructor, Apidologie 38, 566-572.

Le Conte Y., Ellis M.D., Ritter W. (2010) Varroa mites and honey bee health: can Varroa explain part of the colony losses? Apidologie 41, 353-363.

Lodesani M. (1995) Ineffectiveness of Apistan ${ }^{\circledR}$ treatment against the mite Varroa jacobsoni Oud in several districts of Lombardy (Italy), Apidologie 26, 67-72. 
Martín-Hernández R., Higes M., Perez J.L., Nozal M.J., Gomez L., Meana A. (2007) Outcome of colonization of Apis mellifera by Nosema ceranae, Appl. Environ. Microbiol. 73, 6331-6338.

Matheson A. (1995) World bee health update, Bee World 76, 31-39.

Milani N. (1995) The resistance of Varroa jacobsoni Oud. To Pyrethriods - A laboratory assay, Apidologie 26, 415-429.

Milani N. (1999) The resistance of Varroa jacobsoni Oud. to acaricides, Apidologie 30, 229-234.

Moritz R.F.A., Evans J.D. (2007) Honeybee breeding and genomics for resistance to virus infections, in: Aubert M., Ball B., Fries I., Moritz R.F.A., Milani N., Bernadellie I. (Eds.), Virology and the Honey Bee, European Commission, Brussels, pp. 347370.

Moritz R.F.A., Kraus B.F., Kryger P., Crewe R.M. (2007) The size of wild honeybee populations (Apis mellifera) and its implications for the conservation of honeybees, Insect Conserv. 11, 391397.

Navajas M., Migeon A., Alaux C., Martin-Magniette M.L., Robinson G.E., Evans J.D., Cros-Arteil S., Crauser D., Le Conte Y. (2008) Differential gene expression of the honey bee Apis mellifera associated with Varroa destructor infection, BMC Genomics 9, 301.

Nordström S. Fries I., Aarhus A., Hansen H., Korpela S. (1999) Virus infections in Nordic honey bee colonies with no, low or severe Varroa jacobsoni infestations, Apidologie 30, 475-484.

Oldroyd B.P. (2007) What's killing American honey Bees? PLoS Biol 5, e168.

Olofsson T.C., Vasquez A. (2008) Detection and identification of a novel lactic acid bacterial flora within the honey stomach of the honeybee Apis mellifera, Curr. Microbiol. 57, 356-363.

Ongus J.R., Peters D., Bonmatin J.M., Bengsch E., Vlak J.M., van Oers M.M. (2004) Complete sequence of a picorna-like virus of the genus Iflavirus replicating in the mite Varroa destructor, J. Gen. Virol. 85, 3747-3755.

Ouwehand A.C., Salminen S., Isolauri E. (2002) Probiotics: an overview of beneficial effects, Antonie van Leeuwenhoek 82, 279-289.

Paxton R.J., Klee J., Korpela S., Fries I., (2007) Nosema ceranae has infected Apis mellifera in Europe since at least 1998 and may be more virulent than Nosema apis, Apidologie 38, 558-565.

Popova M., Bankova V., Butovska D., Petkov V., Nikolova-Damyanova B., Sabatini A.G., Marcazzan G.L., Bogdanov S. (2004) Validated methods for the quantification of biologically active constituents of poplar-type propolis, Phytochem. Anal. 15, 235-240.
Popova M.P., Bankova V.S., Bogdanov S., Tsvetkova I., Naydenski C., Marcazzan G.L., Sabatini A.G. (2007) Chemical characteristics of poplar type propolis of different geographic origin, Apidologie 38, 306-311.

Potts S.G., Roberts S.P.M., Dean R., Marris G., Brown M., Jones R., Neumann P., Settele J. (2010) Declines of managed honeybees and beekeepers in Europe, J. Apic. Res. 49, 15-22.

Pugia M.J., Sommer R.G., Kuo H.H., Corey P.F., Gopual D.L., Lott J.A. (2004) Near-patient testing for infection using urinalysis and immunochromatography strips, Clin. Chem. Lab. Med. 42, 340-346.

Rennie J., White P.B., Harvey E.J. (1921) Isle of Wight disease in hive bees, Trans. R. Soc. Edinburgh 52, 737-779.

Ribière M., Ball B., Aubert M.F.A. (2008) Natural history and geographical distribution of honeybee viruses, in: Aubert M., Ball B., Fries I., Moritz R.F.A., Milani N., Bernadellie I. (Eds.), Virology and the Honey Bee, European Commission, Brussels, pp. 15-84.

Sammataro D., Gerson U., Needham G. (2000) Parasitic mites of honey bees: Life history, implications, and impact, Annu. Rev. Entomol. 45, 519-548.

Siede R., Berg S., Meixner M. (2008) Effects of symptomless infections with Nosema sp. on honey bee colonies. In: OIE-Symposium Diagnosis and control of bee diseases, Freiburg, Germany, August 26-28.

Simone M., Spivak M. (2010) Propolis and bee health: the natural history and significance of resin use by honey, Apidologie 41, 295-311.

Simone M., Evans J., Spivak M. (2009) Resin collection and social immunity, Evolution, 63, 30163022.

Spivak M. (2001) Mechanisms of American Foulbrood resistance and current research on hygienic behavior, in: Moritz R.F.A. (Ed.), Molecular Mechanisms of Disease Tolerance in Honeybees, BRI Dol, Dol, pp. 155-174.

Stanimirovic Z., Stevanovic J., Jovanovic S., Andjelkovic M. (2005) Evaluation of genotoxic effects of Apitol (R) (cymiazole hydrochloride) in vitro by measurement of sister chromatid exchange, Mutation Res. 588, 152-157.

Stefanidou M., Athanaselis S., Koutselinis A. (2003) The toxicology of honey bee poisoning, Vet. Human Toxicol. 45, 103-105.

Stokstad E. (2007) The case of the empty hives, Science 316, 970-972.

Sumpter D.J.T., Martin S.J. (2004) The dynamics of virus epidemics in Varroa-infested honey bee colonies, J. Anim. Ecol. 73, 51-63. 
Tentcheva D., Gauthier L., Zappulla N., Dainat B., Cousserans F., Colin M.E., Bergoin M. (2004) Prevalence and seasonal variations of six bee viruses in Apis mellifera L. and Varroa destructor mite populations in France, Appl. Environ. Mircobiol. 70, 7185-7191.

Tentcheva D., Gauthier L., Bagny L., Fievet J., Dainat B., Cousserans F., Colin M.E., Bergoin M. (2006) Comparative analysis of deformed wing virus (DWV) RNA in Apis mellifera and Varroa destructor, Apidologie 37, 41-50.

Thompson H.M. (2003) Behavioural effects of pesticides in bees - Their potential for use in risk assessment, Ecotoxicol. 12, 317-330.

Thompson H.M., Brown M.A., Ball R.F., Bew M.H. (2002) First report of Varroa destructor resistance to pyrethroids in the UK, Apidologie 33, 357-366.

Todd J.H., De Miranda J.R., Ball B.V. (2007) Incidence and molecular characterization of viruses found in dying New Zealand honey bee (Apis mellifera) colonies infested with Varroa destructor, Apidologie 38, 345-367.

Tomás-Barberán F.A., Wollenweber E., (1990) Flavonoid aglycones from the leaf surfaces of some Labiatae species, Plant Syst. Evol. 173, 109-118.

Tomás-Barberan F.A., Trowitzsch-Kienast W., Wray V. (1989) Antifungal phloroglucinol derivatives and lypophylic flavonoids from Helichrysum decumbens, Phytochemistry 28, 1613-1615.

Tremolada P., Bernardinelli I., Colombo M., Spreafico M., Vighi M. (2004) Coumaphos distribution in the hive ecosystem: Case study for modeling applications, Ecotoxicology 13, 589-601.

Underwood R., van Engelsdorp D. (2007) Colony Collapse Disorder: Have we seen this before? Bee Cult. 35, 13-18.

van Engelsdorp D., Meixner M.D. (2010) A historical review of managed honey bee populations in Europe and the United States and the factors that may affect them, J. Invertebr. Pathol. 103, S80S95.

van Engelsdorp D., Underwood R., Caron D., Hayes J. (2007) An estimate of managed colony losses in the winter of 2006-2007: A report commissioned by the Apiary Inspectors of America, Am. Bee J. 147, 599-603.

Wallner K. (1999) Varroacides and their residues in bee products, Apidologie 30, 235-248.

Weick J., Thorn R.S. (2002) Effects of acute sublethal exposure to coumaphos or diazinon on acquisition and discrimination of odor stimuli in the honey bee (Hymenoptera: Apidae), J. Econ. Entomol. 95, 227-236.

Weinstock G.M., Robinson G.E., Gibbs R.A. et al. (2006) Insights into social insects from the genome of the honeybee Apis mellifera, Nature 443, 931-949.

Whitfield C.W., Ben-Shahar Y., Brillet C., Leoncini I., Crauser D., Le Conte Y., Rodriguez-Zas S., Robinson G.E. (2006) Genomic dissection of behavioral maturation in the honey bee, Proc. Natl. Acad. Sci. USA 103, 16068-16075.

Wilson W.T., Menapace D.M. (1979) Disappearing disease of honeybees: A survey of the United States, Am. Bee J. 119, 118-119; 184-186; 217.

Yoshiyama, M., Kimura, K. (2009) Bacteria in the gut of Japanese honeybee, Apis cerana japonica, and their antagonistic effect against Paenibacillus larvae, the causal agent of American foulbrood, J. Invertebr. Pathol. 102, 91-96.

Yu S.J., Robinson F.A., Nation J.L. (1984) Detoxication capacity in the honey bee, Apis mellifera L., Pestic. Biochem. Physiol. 22, 360-368.

Yue C., Genersch E. (2005) RT-PCR analysis of Deformed wing virus in honeybees (Apis mellifera) and mites (Varroa destructor), J. Gen. Virol. 86, 3419-3424. 